\title{
Switch On/Off of Hepatitis C and Major Chronic Skin Diseases in Egyptian Patients: Study of Prevalence, the Impact of, Gender, Viral Load and the Severity of Liver Disease
} \author{
Mohamed Abd-almotaleb ${ }^{5}$ \\ ${ }^{1}$ Hepatology department-National Liver Institute-Menoufiya University, Egypt \\ ${ }^{2}$ Dermatology and Venerology department- Faculty of Medicine for Girls, A-lazhar University, Egypt \\ ${ }^{3}$ Public health department, National Liver Institute, Menoufiya University, Egypt \\ ${ }^{4}$ Pediatric department- Faculty of Medicine El-Azhar University, Egypt \\ ${ }^{5}$ Microbiology and Immunology department- National Liver institute, Menoufiya University, Egypt
}

Esam Elshimi ${ }^{1 *}$, Hanan Ali Darwish² ${ }^{2}$ Elsayed Mohamed Abdelaal ${ }^{1}$, Mohamed El Sherify ${ }^{1}$, Wesam Morad ${ }^{3}$, Mohamed Ezzat ${ }^{4}$ and Tawfik

\begin{abstract}
Background and study aim: Hepatitis $\mathrm{C}$ has more than liver disease, a panel of systemic manifestation has been linked to HCV. We aimed in this study to evaluate the prevalence of HCV among major chronic skin diseases in Egyptian patients; we also aimed to study the impact of age, gender, viral load, and the possible role of severity of liver injury between the infected patients and association with skin manifestation.

Patients and methods: Between May 2009 and May 2012, 300 patients with chronic skin diseases (72 lichen planus patients, 70 psoriasis, 56 chronic urticaria, 37 vasculitis and 65 vitiligo) and 100 healthy subjects as a contro - (not known to suffer from skin or liver diseases), were included in this study, HCV antibodies were done primarily for these subject, patients with positive HCV anti bodies were referred to hepatologists to be evaluated further more for: clinical examination regarding the liver disease, HCV viral load, liver profile, auto-immune markers, TSH, serum creatinine, alkaline phosphatase, HBsAg, and liver biopsy. Patients with negative PCR for HCV, patients with positive HBsAg, cirrhotic patients and patients with positive anti-nuclear antibodies were excluded.

Results: HCV prevalence was significantly higher in patients with chronic skin diseases than control group. No statistical significant difference regarding the viral load, age, gender or the severity of liver disease (diagnosed with liver biopsy) between infected patients among chronic skin disease subgroups and HCV patients in the control group.

Conclusion and recommendation: Hepatitis $C$ is highly prevalent among chronic skin disease patients and might be linked to skin disease. Age, gender, viral load and severity of liver disease had no impact on the prevalence of HCV. Hepatitis $\mathrm{C}$ should be rolled out in any patients with chronic skin disease.
\end{abstract}

Keywords: HCV; Skin diseases

\section{Introduction}

Hepatitis C virus (HCV) has been implicated in many systemic diseases other than liver disease. At least 36 extra-hepatic disease manifestations, mainly autoimmune disorders, have been reported to be associated with HCV infection [1]. The list of extra-hepatic manifestations is expanding.

The extra-hepatic disease manifestations have been taken as evidence that HCV has tropism for cells other than hepatocytes, particularly lymphocytes. It has been postulated that HCV infection of lymphocytes is the cause of a many of autoimmune phenomena reported to be associated with HCV infection [2].

The mechanisms by which HCV induces extra-hepatic manifestations-including skin diseases-are still being examined, but several findings have shown the role of HCV both within and outside the liver. First, the HCV surface protein E2, binds to a cell membrane protein CD81. Second, sites on the HCV genome bind to intracellular proteins. Third, low rates of HCV viral production have been found in non-hepatic tissues. Finally, HCV infection may have the ability to present as a generalized systemic disease through its interactions with the immune system by infecting B lymphocytes, monocytes, and polymorphonuclear lymphocytes but not $\mathrm{T}$ lymphocytes $[3,4]$.

Mixed cryoglobulinemia is the most famous disorders linked to
$\mathrm{HCV}$, porphyria cutanea tarda (PCT), cutaneous and/or oral lichen planus (LP), urticaria, pruritus, thrombocytopenic purpura and cutaneous vasculitis also have been linked to chronic HCV infection [5-8].

The extra hepatic manifestation of HCV-including chronic skin diseases - represent the clinical impression of autoimmune phenomena associated with HCV infection, the precise pathogenesis of these extra-hepatic complications is not well fully understood $[9,10]$. Liver cirrhosis and Hepatocellular carcinoma are serious complication from chronic HCV infection, so screening and treatment for chronic HCV infection is critical to decrease morbidity and mortality among infected people, additionally early diagnosis of $\mathrm{HCV}$ and eventually treatment could improve the associated extra-hepatic manifestation including skin diseases. We aimed in this study to investigate the positive link

${ }^{*}$ Corresponding author: Esam Elshimi, Hepatology department-National Live Institute-Menoufiya University, Egypt, E-mail: eelshimi@liver-eg.org

Received April 15, 2013; Accepted June 19, 2013; Published June 26, 2013

Citation: Elshimi E, Darwish HA, Abdelaal EM, Sherify ME, Morad W, et al. (2013) Switch On/Off of Hepatitis C and Major Chronic Skin Diseases in Egyptian Patients: Study of Prevalence, the Impact of, Gender, Viral Load and the Severity of Liver Disease. J Liver 2: 121. doi:10.4172/2167-0889.1000121

Copyright: ( 2013 Elshimi E, et al. This is an open-access article distributed unde the terms of the Creative Commons Attribution License, which permits unrestricted use, distribution, and reproduction in any medium, provided the original author and source are credited. 
Citation: Elshimi E, Darwish HA, Abdelaal EM, Sherify ME, Morad W, et al. (2013) Switch On/Off of Hepatitis C and Major Chronic Skin Diseases in Egyptian Patients: Study of Prevalence, the Impact of, Gender, Viral Load and the Severity of Liver Disease. J Liver 2: 121. doi:10.4172/21670889.1000121

Page 2 of 7

between chronic HCV infection and some of famous chronic skin disease.

\section{Study Design}

\section{Patients and methods}

This study was a prospective controlled study, it was conducted in the out patients clinics-Dermatology department-Al-Azharaa HospitalAlazhar University (a tertiary referral center for skin disease), where all patients with chronic skin diseases (chronic urticaria, vasculitis, lichen plannus, vitilligo and psoriasis) were invited to participate in this study and the out patients clinics-Hepatology department-National Liver Institute- Menoufiya University (a tertiary referral center for liver disease), between May 2009 and May 2012. 300 patients with chronic skin disease were recruited to participate in this study, blood samples were collected if the patients agreed to participate in this study; they were 179 male patients (age range; $10-56$ years) and 121 female patients (age range 9-51 years). 70 cases had psoriasis, 52 cases had Lichen Planes, 55 cases had Chronic Urticaria and 29 cases had Vasculitis and the rest had Vitiligo. All patients were reviewed by experienced Dermatologist before referral to Hepatologists. Cases of Psoriasis, Chronic urticaria, Vitiligo and Lichen Planus were diagnosed clinically; cases of vasculitis were diagnosed clinically and by skin biopsy. One hundred apparently healthy controls were selected to participate in this study; they were blood donors or potential donors for living liver transplantation attended to blood bank or to the liver transplantation clinic. They were reviewed by history and clinically for liver disease and any chronic skin diseases. Their ages ranged from 21-49 years. They were 67 males and 33 females.

\section{Exclusion criteria}

We excluded patients with positive HCV anti bodies and negative HCV PCR, cirrhotic patients, combined HCV and hepatitis B virus and patients with an overlap diseases (autoimmune hepatitis and HCV). Patients and controls with previously known their HCV antibodies status were also excluded.

Patient consent and Ethical Committee approval were taken according to National Liver Institute Ethical committee.

All subjects were subjected to complete history taking and clinical examination.

Liver function tests: HCV anti bodies using 4th generation ELIZA. Total and direct bilirubin, alanine aminotransferase (ALT), aspartate aminotransferase (AST), alkaline phosphatase (ALP), gamma glutamyle transpeptidase (GGT), total proteins and serum albumin, Prothrombin time and INR, HBs Ag, ANA, Alpha fetoprotein, anti bilharzial anti body, TSH, fasting blood sugar, quantitative HCV PCR, abdominal ultrasoundand liver biopsy. Liver biopsies were revised by experienced pathologists and they were graded according Ishak scoring system. Skin biopsies were taken from some cases to prove the diagnosis of skin disease.

\section{Statistical Analysis}

Data was collected statistically analyzed using SPSS (statistical package for social science) program version 13 for windows and for all the analysis a $p$ value $<0.05$ was considered statistically significant: in which the data were shown as mean, range or value and $95 \%$ confidence interval (95\% CI) and frequency and percent. Chi square test was done for qualitative variable analysis. Student $\mathrm{t}$ - test was done for normally distributed quantitative variables to measure mean and standard deviation. Multivariate logistic regression analysis was performed on factors which were significantly different in a uni-variate analysis between patients of both groups in order to determine adjusted Odds ratio (OR) and 95\% confidence interval (CI) to detect the factors that are independently associated with the presence of the factor under the study.

\section{Results and Discussion}

Hepatitis $\mathrm{C}$ virus in most patients primarily, and in most patients exclusively, confined to liver, however a wide varieties of extra-hepatic manifestations have been reported [3]. In some of these patients the extra-hepatic manifestation is the triggering attention to seek medical advice.

In our series we examined 300 patients with chronic skin diseases; 70 cases of psoriasis, 72 cases of lichen planus, 65 cases of chronic urticaria, 37 cases of vasculitis and 56 cases of vitilligo in relation to 100 subjects not known to have chronic HCV infection or chronic skin diseases as a control group.

In the present study chronic HCV infection was found in $51.66 \%$ in cases of chronic skin diseases group compared to $19 \%$ in control group $(\mathrm{p}<0.01)$. This raised a statistically significant difference regarding the prevalence of chronic HCV infection in chronic skin diseases (Table 1).

Bongiorno et al. [11] detected HCV antibodies in $27.91 \%$ and combined HCV and HBV infection in $3.52 \%$ of their series. They assumed that HCV has reservoir other than hepatocytes; blood lymphocytes and mononuclear cells. HCV can invade skin with replication and damaging the keratinocytes [11]. Also Halawani et al. detected significantly higher prevalence of $\mathrm{HCV}$ antibodies in patients of chronic skin disease patients [12]. However the authors did not exclude patients who are co-infected with HBV and patients with auto-

\begin{tabular}{|c|c|c|}
\hline & Control $n=19$ & Chronic skin diseases $n=300$ \\
\hline $\begin{array}{l}\text { Gender } \\
\text { Males } \\
\text { females }\end{array}$ & $\begin{array}{l}67(67.0) \\
33(33.0)\end{array}$ & $\begin{array}{l}179(59.7) \\
121(40.3)\end{array}$ \\
\hline $\begin{array}{l}\text { Age } \\
<40 \\
\geq 40\end{array}$ & $\begin{array}{l}21(21.0) \\
79(79.0)\end{array}$ & $\begin{array}{l}134(44.7) \\
166(55.3)\end{array}$ \\
\hline $\begin{array}{c}\text { HCV } \\
\text { - Positive } \\
\text { - Negative }\end{array}$ & $\begin{array}{l}19(19.0) \\
81(81.0)\end{array}$ & $\begin{array}{l}155(51.7) \\
145(48.3)\end{array}$ \\
\hline $\begin{array}{c}\text { ALT } \\
\text { Min-Max. } \\
\text { Mean (SD) }\end{array}$ & $\begin{array}{l}22.56(38.26) \\
30.64(19.36)\end{array}$ & $\begin{array}{l}38.2(64.31) \\
58.12(38.12)\end{array}$ \\
\hline $\begin{array}{c}\text { AST } \\
\text { Min-Max. } \\
\text { Mean (SD) }\end{array}$ & $\begin{array}{c}24.6(42.6) \\
33.64(23.55)\end{array}$ & $\begin{array}{c}31.5(101.26) \\
60(41.1)\end{array}$ \\
\hline $\begin{array}{c}\text { PC } \\
\text { Min-Max. } \\
\text { Mean (SD) }\end{array}$ & $\begin{array}{l}80.26(100.0) \\
92.82(10.98)\end{array}$ & $\begin{array}{l}78.6(96.25) \\
95.65(9.33)\end{array}$ \\
\hline $\begin{array}{c}\text { GGT } \\
\text { Min-Max. } \\
\text { Mean (SD) }\end{array}$ & $\begin{array}{c}28.2(51.9) \\
45.56(20.01)\end{array}$ & $\begin{array}{c}33.1(86.8) \\
75.94(55.92)\end{array}$ \\
\hline $\begin{array}{l}\text { Albumin } \\
\text { Min-Max. } \\
\text { Mean (SD) }\end{array}$ & $\begin{array}{l}3.21(5.33) \\
4.41(0.63)\end{array}$ & $\begin{array}{l}2.96(6.12) \\
4.39(0.66)\end{array}$ \\
\hline $\begin{array}{l}\text { Total bilirubin } \\
\text { Min-Max. } \\
\text { Mean (SD) }\end{array}$ & $\begin{array}{c}0.45(1.2) \\
0.85(0.27)\end{array}$ & $\begin{array}{l}0.57(1.64) \\
0.98(0.56)\end{array}$ \\
\hline $\begin{array}{c}\text { PCR } \\
\text { Min-Max. } \\
\text { Mean (SD) }\end{array}$ & $\begin{array}{c}0.0(810.0) \\
799.25(51.6)\end{array}$ & $\begin{array}{c}910.26(1345.35) \\
1010.76(55.36)\end{array}$ \\
\hline
\end{tabular}

Table 1: Descriptive statistics of all variables in studied groups. 
Citation: Elshimi E, Darwish HA, Abdelaal EM, Sherify ME, Morad W, et al. (2013) Switch On/Off of Hepatitis C and Major Chronic Skin Diseases in Egyptian Patients: Study of Prevalence, the Impact of, Gender, Viral Load and the Severity of Liver Disease. J Liver 2: 121. doi:10.4172/21670889.1000121

Page 3 of 7

immune hepatitis. Additionally they did not exclude patients who cleared the virus spontaneously.

Crowson et al. detected HCV RNA in skin biopsies of chronic skin diseases and hepatitis C [13]. However Mangia et al. did not detect the HCV RNA in any skin biopsies from patients with Lichen Planus and cutaneous vasculitis associated with mixed cryoglobulinemia. They concluded that the positiveassociation between cutaneous vasculitis and lichen planus and chronic hepatitis $\mathrm{C}$ patients is unlikely to be due to HCV skin replication [14].

In the present study; chronic HCV infection was reported in $56.9 \%$ of cases of Lichen Planus Vs $19 \%$ of control group; p value $<0.01$ (Table 2).

The association between Lichen Planus and HCV had been reported in early nineties in the last century by Jubert et al. [15]. Since then, a lot of reports had been studied to prove or exclude this association.

Nagao et al. detected HCV antibodies in $62 \%$ and HCV RNA in $60 \%$ of Lichen Planus patients versus 7.9\% in control group. They suggest that the presence anti epithelial antibodies may be the cause [16]. Tanei et al. detected anti-HCV antibodies in sera of $37.8 \%$ of Lichen Planus patients; this was significantly higher than the control subjects [17]. But the authors did not exclude patients with negative viremia or coinfected patients by HBV or association with autoimmune disease.

Dupond et al. detected HCV antibodies among patients with erosive Lichen Planus in $29 \%$ of patients versus 1 to $2 \%$ "overall prevalence of chronic carriers of HCV in southern France [18]. Mignogna et al. found HCV antibodies was $28.8 \%$ in patients with oral lichen planus versus only $3 \%$ in their control group [19]. Also Bagan et al. [20] found the prevalence of HCV in biopsy-proven oral Lichen Planus in $23 \%$ Vs $5 \%$ in controls. They concluded the presence of chronic foci of infection may be a possible cause of Lichen Planus. In Spain and Italy, $11.3 \%$ and $13 \%$ of patients with oral Lichen Planus were found to be anti-HCV-positive [21,22].

In a retrospective chart review of 229 consecutive patients with oral Lichen Planus, HCV exposure status was known for 31 patients, of whom 14 were $\mathrm{HCV}$ antibody- positive [23].

Nagao et al. [16] investigated oral lesions in 59 anti-HCV-positive patients, 57 were HCV RNA-positive). They suggested that the positive alteration in epidermal antigenecity induced by HCV can interact with $\mathrm{T}$ cell that increases their production of interferon gamma which in turn stimulates keratinocytes to express HALA -DR to be destroyed by $\mathrm{T}$ cells [24].

Another explanation came from interferon role in exacerbation or improvement of Lichen Planus; the interferon increased keratinocyte expression of HLA DR II molecules and the intercellular adhesion molecule-1, leading to the epidermal migration of the activated $\mathrm{T}$ cells expressing high levels of lymphocyte function associated antigen-123 with adhesion to keratinocytes leading to its toxicity $[25,26]$.

The prevalence of HCV infection was not statistically different between patients with Lichen Planus and patients with dermatoses other than lichen planus [27]. However, this was not proved by many authors [28-30]. However, most of these studies were carried out on small number of patients with different ethnic and genetic variables and some were uncontrolled.

In the present study; the chronic HCV infection was reported in $47.1 \%$ of psoriatic patients vs. $19 \%$ of control group ( $<<0.001$ ), this raised a statistically significant difference between both groups (Table $3)$.

Several studies supported our findings; Chouela et al. [31] detected the prevalence of HCV infection in psoriatic patients $7.6 \%$ compared to $1.2 \%$ in 60,000 blood donors. They stated that the link between both diseases might argued to the viral replication in hepatic tissues and the production of auto-antibodies against both hepatocytes and keratinocytes [31], Yamamoto et al. [32] detected messenger RNA in the skin lesion of patients with psoriasis vulgaris and generalized pustular psoriasis. The presence of $\mathrm{m}$ RNA might suggest that the $\mathrm{HCV}$ is one of triggering events for psoriasis or HCV induced direct keratinocyte cytopathic effect and or induction of autoimmune reaction or through immune complex formation [32]. But the study did not explain why some patients developed psoriasis and others not and why others developed psoriasis only and not another dermatoses.

Taglione et al. [33] found the prevalence of HCV infection in 12\% and $10 \%$ among psoriatic arthritis and without arthritis respectively, they concluded that this was statistically significant in comparison to general population [33]. In addition Chouela et al. [31] concluded also that in the presence of liver disease in psoriatic patients, HCV infection should be considered as an alternative diagnosis. They attributed the

\begin{tabular}{|c|c|c|c|c|c|c|}
\hline & Groups & $\mathbf{N}$ & Mean & Standard Deviations & $\mathbf{T}$ & $\mathbf{P}$ \\
\hline \multirow{2}{*}{ ALT } & Patients & 300 & 58.12 & 38.122 & \multirow{2}{*}{5.854} & \multirow{2}{*}{$<0.0001$} \\
\hline & Control & 100 & 30.64 & 19.364 & & \\
\hline \multirow{2}{*}{ AST } & Patients & 300 & 60.00 & 41.101 & \multirow{2}{*}{4.983} & \multirow{2}{*}{$<0.0001$} \\
\hline & Control & 100 & 33.64 & 23.545 & & \\
\hline \multirow{2}{*}{ PC } & Patients & 300 & 95.65 & 9.329 & \multirow{2}{*}{1.649} & \multirow{2}{*}{0.101} \\
\hline & Control & 100 & 92.82 & 10.982 & & \\
\hline \multirow{2}{*}{ TBIL } & Patients & 300 & .980 & .5610 & \multirow{2}{*}{1.814} & \multirow{2}{*}{0.072} \\
\hline & Control & 100 & .850 & .2700 & & \\
\hline \multirow{2}{*}{ GGT } & Patients & 300 & 75.94 & 55.917 & \multirow{2}{*}{4.848} & \multirow{2}{*}{$<0.0001$} \\
\hline & Control & 100 & 45.56 & 20.009 & & \\
\hline \multirow{2}{*}{ ALB } & Patients & 300 & 4.39 & 0.662 & \multirow{2}{*}{-0.177} & \multirow{2}{*}{0.860} \\
\hline & Control & 100 & 4.41 & 0.631 & & \\
\hline
\end{tabular}

Table (2) illustrated the mean and standard deviation for both group of the study as regard liver function tests.

$T=T$ test, $P=$ Predictive value, $A L T=a$ anine transaminase $A S T=a s p a r t a t e$ transaminase, $\mathrm{PC}=$ prothrombin concentration, $\mathrm{TBI}=$ =total bilrubin $\mathrm{ALB}=$ albumin, GGT=gamma glutamyle transpeptidase

Table 2: The laboratory results of the studied groups.

\begin{tabular}{|c|c|c|c|c|}
\hline Studied variables & HCV positive & HCV negative & Chi square test & p-value \\
\hline Lichen planus $n=72$ & $41(56.9)$ & 31 & \multirow[b]{2}{*}{26.53} & \multirow[b]{2}{*}{$<0.01$} \\
\hline Control $n=100$ & 19 & 81 & & \\
\hline Psoriasis $n=70$ & $33(47.1 \%)$ & 37 & \multirow[b]{2}{*}{15.36} & \multirow[b]{2}{*}{$<0.01$} \\
\hline Control $n=100$ & 19 & 81 & & \\
\hline $\begin{array}{l}\text { Chronic Urticaria } \\
n=65\end{array}$ & $34(52.3 \%)$ & 31 & \multirow{2}{*}{20.04} & \multirow{2}{*}{$<0.01$} \\
\hline Control $n=100$ & 19 & 81 & & \\
\hline Vasculitis $n=37$ & $20(54 \%)$ & 17 & \multirow[b]{2}{*}{16.38} & \multirow[b]{2}{*}{$<0.01$} \\
\hline Control $n=100$ & 19 & 81 & & \\
\hline Vitilgo $n=56$ & $27(48.2 \%)$ & 29 & \multirow[b]{2}{*}{14.74} & \multirow[b]{2}{*}{$<0.01$} \\
\hline Control $n=100$ & 19 & 81 & & \\
\hline $\begin{array}{l}\text { Total chronic skin } \\
\text { disease } n=300\end{array}$ & $155(51.66 \%)$ & 145 & \multirow{2}{*}{32.56} & \multirow{2}{*}{$<0.01$} \\
\hline Control $n=100$ & $19(19 \%)$ & 81 & & \\
\hline
\end{tabular}

Table 3 showed Gender, age, mean viral load and severity of liver disease between different studied groups.

Table 3: The prevalence of chronic HCV infection in control and different chronic skin diseases groups. 
Citation: Elshimi E, Darwish HA, Abdelaal EM, Sherify ME, Morad W, et al. (2013) Switch On/Off of Hepatitis C and Major Chronic Skin Diseases in Egyptian Patients: Study of Prevalence, the Impact of, Gender, Viral Load and the Severity of Liver Disease. J Liver 2: 121. doi:10.4172/21670889.1000121

Page 4 of 7

high anti-HCV prevalence in this series is to infection by in apparent parenteral routes, through minute skin abrasions [31]. This could explain the positive association between psoriasis and HCV but link between newly developed or re-occurrence of psoriasis after interferon $[34,35]$ needs additional etiogenesis.

Exacerbations of psoriasis have usually occurred between one and six weeks up to six months after the beginning of IFN therapy, withdrawal of IFN results in psoriasis improvement in most cases. However the mechanism is not well understood but immunemodulatory effects might be considered [36].

In the present study the prevalence of chronic HCV in vasculitis was $54 \%$ vs. $19 \%$ in control group ( $p<0.001)$, this aroused a high statistically significant difference.

In the present study the prevalence of chronic HCV in vasculitis patients was $(54 \% \mathrm{p}$ value $<0.001)$ vs. $19 \%$ in control group, this aroused a high statistically significant difference.

Our data is supported by Agnello and Abel Glel [37] who detected HCV RNA in some vessel walls, and in skin and ductal epithelium and vascular endothelium only in inflamed, but not in normal skin in chronic HCV patients. Cryoglobulins showed HCV monomeric IgM, and monomeric IgG, with little or no immune complexes. The extent of the lesions correlated with levels of viremia. Up-regulation of LDL receptors on keratinocytes was detected in inflamed, but not in normal skin [37].

Ignatova et al. detected mixed cryoglobinemia in $43 \%$ of patients with chronic hepatitis C. $30 \%$ of those patients had clinical signs of vasculitis [38].

However, not all cases of HCV related vasculitis have detectable cryogobinemia [39], Terrier et al. [40] described 12 HCV RNA positive patients with histologically proven vasculitis without mixed cryogolbinemia and compared them to $48 \mathrm{HCV}$ related vasculitis with mixed cryoglobinemia, they detected similar course disease except for lower rates of arthralgias ( $33 \%$ vs. $71 \% ; \mathrm{p}=0.02)$ and purpura $(50 \%$ vs. $83 \% ; \mathrm{p}=0.03$ ) with similar histological features and response rate to current anti viral therapy [40].

The prognosis of HCV related systemic vasculitis is related to severity liver fibrosis and the severity of vasculitis and the use of immunosuppressant is associated with negative impact [41].

In contrast Batisse et al. reported exacerbation of vasculitis during treatment with peginterferon and they expected that the long half-life of peginterferon might explain the long-lasting symptoms of vasculitis [42]. However host related or virus related factors might affect the results.

In our study, the prevalence of chronic $\mathrm{HCV}$ in chronic urticaria patients was $52 \%$ vs. $19 \%$ in control group $(\mathrm{p}<0.001 \%)$ and this was statistically significant (Table 3 ).

Kanazawa et al. found the presence of anti-HCV antibodies in $24 \%$ and HCV-RNA in $22 \%$ of chronic urticaria patients. They argued this finding to the immune mechanisms and molecular mimicry [43]. Similarly Schwaber et al. studied 28 patients with chronic urticaria; 11 (39\%) of this group had HCV antibodies, and 8 (28\%) were positive for HCV PCR [44].

Raslan et al. assessed the dermatological manifestations in a group of chronic HCV Egyptian patients, $45.8 \%$ had dermatological manifestations: most of the patient had pruritus (26.5\%), aphthous ulcer (3.9\%), Lichen Planus (3.9\%), leukocytoclastic vasculitis (2.6\%), psoriasis $(1.9 \%)$, tinea versicolor $(1.3 \%)$ and other conditions $(5.8 \%)$ [45]. But some of the studied patients were cirrhotic and most of patients with skin disease were cirrhotic, some of skin manifestation might related to liver cirrhosis rather than chronic HCV infection, however this should be assessed and evaluated carefully.

Cunha et al. evaluated 201 patients, 108 were co-infected with HCV and HIV, the rest of the patients were positive only for HCV infection. Pruritus tended to be more common in isolated HCV. Isolated HCV patients also had significantly more dermatological disorders; higher prevalence rate of pigmentation disorders as verruca vulgaris and facial melasma [46]. However these data needs further validation as it seems that HIV reverse the extra-hepatic events of $\mathrm{HCV}$, in addition palmar erythema might related to the effect of liver damage and cirrhosis induced by HCV. Also varicose veins have a lot of different etiologies and should be excluded before adding it as HCV related extra-hepatic manifestation

Dega et al. retrospectively evaluated 27 patients with chronic urticaria [10]. 15 cases were HCV positive and 13 out of 15 were positive for HCV PCR [47]. Also, Siddique et al. assayed the prevalence of chronic $\mathrm{HCV}$ infection and detected a high prevalence of $\mathrm{HCV}$ among chronic urticaria patients [47].

In contrast Cribier et al. and Zauli et al. evaluated the prevalence of HCV antibodies in patients with urticaria, they detected no significant association between HCV infection and chronic urticaria $[48,49]$.

In our series 56 patients with vitiligo were included, 27 of them (48.2\%) had HCV infection Vs $19 \%$ in control $(\mathrm{p}<0.01)$. This was statistically significant (Table 2).

Little research reports about the potential role of HCV infection in vitiligo with no clear association. A significantly greater proportion of HCV-infected patients had vitiligo. However the potential role may argued to the possible direct cytotoxicity and inflammation triggered by the virus $[50,51]$.

The possible role may be supported by some evidences. First, the higher prevalence of $\mathrm{HCV}$ antibodies in vitiligo patients in relation to control, as in our study; Second, improvement of color depigmentation in some patients receiving the standard of care therapy locally at the injection site of interferon in some case reports; The Third development of new cases in some patients receiving interferon. We reported in our series, a case of newly developed vitilligo 3 weeks after the end of treatment ( 48 weeks of interferon therapy), the patient had end of treatment failure of response and his skin manifestation did not improved spontaneously.

Kang et al. [52], and Tomasiewicz et al. [53] reported cases of vitiligo that occurred during the course of treatment with Peg-IFN and RBV which did not resolve and required post interferon therapy. A similar case report of vitilligo induced but all skin lesions resolved spontaneously [54]. This impressed us that vitiligo may be interferon induced through induction of anti-melanocyte auto-antibodies or activation of cytotoxic $\mathrm{T}$ cells.

However Akbayir et al. found only one HCV infection proved by RT-PCR in 102 vitiligo patients [55].

Possible explanation for IFN induced vitiligo might be due to the well-known immune-modulator effect that can lead to the pathogenesis of vitiligo; enhancing the lymphocyte attachment to endothelial cells and deposition of immune complexes and vasculitis. Locally IFN can 
Citation: Elshimi E, Darwish HA, Abdelaal EM, Sherify ME, Morad W, et al. (2013) Switch On/Off of Hepatitis C and Major Chronic Skin Diseases in Egyptian Patients: Study of Prevalence, the Impact of, Gender, Viral Load and the Severity of Liver Disease. J Liver 2: 121. doi:10.4172/21670889.1000121

Page 5 of 7

induce a direct cytotoxic T-cell-mediated immune response destruction of melanocytes, with a resultant local destruction of melanocytes. HCV has high rate of replication and mutation (quasi-species) leading to repeated activation of immune cells and immunological pathways or may be involved

In our series we compared the severity of the liver disease and viral load between the positive cases of HCV among the control group and skin disease patients infected by HCV in different sub-groups (Tables 3 and 4). It was expected to find some variation between them but we detected that the difference was not significant. This might signify that the viral load and the severity of liver burden had no impact on the development of extra-hepatic manifestation in general, particularly the skin disease. In the literature no available data studied the impact of these factors and further evaluation might be required to prove or exclude this conclusion (Table 4).

As regards effect of Gender, there was no significant difference as regards gender distribution (Table 4). Our data supposed that older age might have an impact on the association with extra-hepatic manifestation of HCV (Tables 4-6). However in the literature there was no enough data discussing the impact of viral load, gender of the studied patient or the severity of liver disease.

Possible reasons for variability in results may due to some methodological variation as selection bias. In addition in some studies, the diagnosis was not proved by detection of HCV RNA.

\section{Conclusion and Recommendations}

Our findings concluded that the chronic HCV infection is under estimated among patients with chronic skin diseases. This signifies the possible etiologic role of $\mathrm{HCV}$ infection in initiating and promoting chronic skin diseases. However further studies are needed to explain this high prevalence, the possible genetic and immunologic role, the selection of some patients developed skin disease and not all HCV

\begin{tabular}{|c|c|c|c|c|c|c|c|}
\hline & Control $n=19$ & Psoriasis $n=33$ & Lichen $p$ n=41 & Vas $n=20$ & Vitiligo $n=27$ & Ch U n=34 & Total skin diseases $n=155$ \\
\hline Gender Males/females & $12 / 7$ & $20 / 13$ & 23/18 & $12 / 8$ & 16/11 & 19/15 & $90 / 65$ \\
\hline Age $<40 / \geq 40$ & $8 / 11$ & $13 / 20$ & $17 / 24$ & $9 / 11$ & $12 / 15$ & $16 / 18$ & $67 / 88$ \\
\hline Viral load & $780.35 \pm 45.2$ & $797.03 \pm 46.7$ & $789.50 \pm 45.9$ & $800.10 \pm 45.34$ & $805.22 \pm 41.4$ & $799.21 \pm 44.70$ & $803.46 \pm 49.21$ \\
\hline $\begin{array}{c}\text { Severity of liver disease } \\
\text { F0-F3/F4-6 }\end{array}$ & $11 / 8$ & $18 / 15$ & $21 / 20$ & $12 / 8$ & $17 / 10$ & $23 / 11$ & $83 / 72$ \\
\hline
\end{tabular}

Table 4: Gender, age, viral load and liver biopsy results in different studied groups.

\begin{tabular}{|c|c|c|c|c|}
\hline Groups & $p$ - value of Age & $p$ - value of gender & p- value of liver fibrosis & p- value of viral load \\
\hline control psoriasis & 0.85 & 0.86 & 0.81 & 0.22 \\
\hline control lichen P. & 0.96 & 0.61 & 0.63 & 0.47 \\
\hline control vasculitis & 0.86 & 0.84 & 0.89 & 0.18 \\
\hline control vitiligo & 0.87 & 0.79 & 0.83 & 0.06 \\
\hline Control Chronic urticaria & 0.73 & 0.61 & 0.48 & 0.15 \\
\hline control total skin group & 0.90 & 0.87 & 0.35 & 0.053 \\
\hline psoriasis lichen & 0.86 & 0.69 & 0.78 & 0.49 \\
\hline psoriasis vasculitis & 0.69 & 0.97 & 0.69 & 0.82 \\
\hline psoriasis vitiligo & 0.69 & 0.92 & 0.51 & 0.48 \\
\hline psoriasis Chronic urticaria & 0.53 & 0.69 & 0.27 & 0.85 \\
\hline psoriasis total skin group & 0.89 & 0.94 & 0.39 & 0.49 \\
\hline lichen vasculitis & 0.79 & 0.77 & 0.52 & 0.39 \\
\hline lichen vitiligo & 0.81 & 0.79 & 0.34 & 0.16 \\
\hline lichen Chronic urticaria & 0.63 & 0.99 & 0.15 & 0.36 \\
\hline lichen total skin group & 0.92 & 0.55 & 0.59 & 0.1 \\
\hline vasculitis Vitiligo & 0.97 & 0.96 & 0.84 & 0.69 \\
\hline vasculitis Chronic urticaria & 0.88 & 0.77 & 0.57 & 0.94 \\
\hline vasculitis total skin group & 0.71 & 0.91 & 0.25 & 077 \\
\hline vitiligo Chronic urticaria & 0.84 & 0.79 & 0.7 & 0.59 \\
\hline vitiligo total skin group & 0.71 & 0.84 & 0.11 & 0.86 \\
\hline Chronic urticaria total skin group & 0.49 & 0.56 & 0.051 & 0.64 \\
\hline
\end{tabular}

Table 5: $p$ value of different studied group regarding age, gender, viral load and severity of liver biopsy, No significant association between skin disease and age, gender viral load and severity of liver disease.

\begin{tabular}{|c|c|c|c|c|c|}
\hline & \multirow{2}{*}{ B } & \multirow{2}{*}{$p$ - value } & \multirow{2}{*}{ OR } & \multicolumn{2}{|c|}{$95.0 \%$ C.I. for OR } \\
\hline & & & & Upper & Lower \\
\hline B Constant & -1.035 & & & & \\
\hline Lichen planus & -0.297 & $>0.05$ & 0.743 & 1.308 & 0.422 \\
\hline Psoriasis & -0.260 & $>0.05$ & 0.771 & 1.358 & 0.437 \\
\hline Chronic Urticaria & -0.165 & $>0.05$ & 0.848 & 0.480 & 1.500 \\
\hline Vasculitis & 1.189 & $<0.01$ & 3.284 & 1.672 & 6.449 \\
\hline Vitilgo & 0.864 & $<0.01$ & 2.372 & 1.254 & 4.485 \\
\hline Total chronic skin disease & -1.517 & $<0.01$ & 0.219 & 0.127 & 0.380 \\
\hline
\end{tabular}

Table 6: Multivariable logistic regression analysis of skin diseases related to chronic HCV disease. 
Citation: Elshimi E, Darwish HA, Abdelaal EM, Sherify ME, Morad W, et al. (2013) Switch On/Off of Hepatitis C and Major Chronic Skin Diseases in Egyptian Patients: Study of Prevalence, the Impact of, Gender, Viral Load and the Severity of Liver Disease. J Liver 2: 121. doi:10.4172/21670889.1000121

Page 6 of 7

patients, the effect of interferon treatment on skin disease and the selection of specific skin disease in each chronic HCV patient to occur. We recommend screening all patients with chronic skin diseases for HCV infection for early diagnosis and treatments.

\section{References}

1. Agnello V, De Rosa FG (2004) Extrahepatic disease manifestations of HCV infection: some current issues. J Hepatol 40: 341-352.

2. Matignon M, Cacoub P, Colombat M, Saadoun D, Brocheriou I, et al. (2009) Clinical and morphologic spectrum of renal involvement in patients with mixed cryoglobulinemia without evidence of hepatitis $C$ virus infection. Medicine (Baltimore) 88: 341-348.

3. Cacoub P, Lidove O, Maisonobe T, Duhaut P, Thibault V, et al.( 2002) Interferon-alpha and ribavirin treatment in patients with hepatitis $C$ virus-related systemic vasculitis. Arthritis Rheum 46: 3317-3326.

4. Bernacchi E, Civita LL, Caproni M, Zignego AL, Bianchi B,et al. Hepatitis C virus (HCV) in cryoglobulinaemic leukocytoclastic vasculitis (LCV): could the presence of HCV in skin lesions be related to T CD8+ lymphocytes, HLA-DR and ICAM-1 expression? Exp Dermatol 8: 480-486.

5. http://emedicine.medscape.com/article/1134161-clinical

6. Galossi A,Guarisco R, Bellis L, Puoti C(2007) Extrahepatic manifestations of chronic HCV infection. J. Gastrointestin. Liver Dis 16: 65-73.

7. Poljacki M, Gajinov Z, Ivkov M, Matic' M, Golusin Z (2000) Skin diseases and hepatitis virus $C$ infection. Med. Pregl 53: 141-145.

8. Cordel N, Chosidow O, France'sC (2000) Cutaneous disorders associated with hepatitis C virus infection. Ann Med Interne 151: 46-52.

9. Pyropoulos NT, Reddy KR (2001) Extrahepatic manifestations of chronic vira hepatitis. Curr Gastroenterol Rep 3: 71-78.

10. Dega H, Francès C, Dupin N, Lebre C, Simantov A, et al. (1998) Pruritus and the hepatitis C virus. The MULTIVIRC Unit. Ann Dermatol Venereol 125: 9-12.

11. Bongiorno MR, Pistone G, Aricò G (2002) Hepatitis B and hepatitis C virus infections in dermatological patients in west Sicily: a seroepidemiological study. J Eur Acad Dermatol Venereol 16: 43- 46

12. Halawani M, Balbisi A, Alotaibi H, Fahed A, Talal MB (2010) The prevalence of HCV antibodies in skin disease patients in Saudi Arabia Saudi Pharmaceutical Journal 18: 35-39.

13. Crowson A N, Nuovo G, Ferri C, Magro CM (2003) The dermatopathologic manifestations of hepatitis $C$ infection: a clinical, histological, and molecular assessment of 35 cases. Hum. Pathol 34: 573-579.

14. Mangia A, Clemente R, Musto $P$, Cascavilla I, La Floresta $P$, et al. (1996) Hepatitis $C$ virus infection and monoclonal gammopathies not associated with cryoglobulinemia. Leukemia 10: 1209-1213.

15. Jubert C, Pawlotsky JM, Pouget F, Andre C, DeForges L, et al. (1994) Lichen planus and $C$ virus-related chronic active hepatitis. Arch Dermatol 130: 73-76.

16. Nagao Y, Sata M, Tanikawa K, Itoh K, Kameyama T ( 1995) Lichen planus and hepatitis $C$ virus in the Northern Kyushu region of Japan. Eur J Clin Invest 25: 910-914

17. Tanei R, Watanabe K, Nishiyama S (1995) Clinical and histopathologic analysis of the relationship between lichen planus and chronic hepatitis C. J Dermatol 22: $316-323$

18. Dupond AS, Lacour JP, Lafont C, Ortonne JP (1998) Prevalence of hepatitis C virus in oral erosive lichen. Ann Dermatol Venereol 125: 676- 678.

19. Mignogna MD, Lo Muzio L, Favia G, Mignogna RE, Carbone R, et al. (1998) Oral lichen planus and HCV infection: a clinical evaluation of 263 cases. Int J Dermatol 37: 575-578.

20. Bagán JV, Ramón C, González L, Diago M, Milián MA, et al. (1998) Preliminary investigation of the association of oral lichen planus and hepatitis $C$. Oral Surg Oral Med Oral Pathol Radiol Endod 85:532-536.

21. Romero MA, Seoane J, Varela-Centelles P, Diz-Dios P, Otero XL (2002) Clinica and pathological characteristics of oral lichen planus in hepatitis C-positive and -negative patients. Clin Otolaryngol 27: 22-26.

22. Rossi L, Colasanto S (2000) Clinical considerations and statistical analysis on 100 patients with oral lichen planus. Minerva Stomatol 49: 393-398.
23. Chainani-Wu N, Silverman S Jr, Lozada-Nur F, Mayer P, Watson JJ ( 2001) Ora lichen planus: patient profile, disease progression and treatment responses. $J$ Am Dent Assoc 132: 901-909.

24. NagaoY, Sata M, Fukuizumi K, Ryu F, Ueno T (2000) High incidence of ora lichen planus in an HCV hyperendemic area. Gastroenterology 119: 882-883.

25. Pavio N, Lai MM (2003) The hepatitis C virus persistence: how to evade the immune system? J Biosci 28: 287-304.

26. Cribier B, Garnier C, Laustriat D, Heid E (1994) Lichen planus and hepatitis C virus infection: an epidemiologic study. J Am Acad Dermatol 31: 1070-1072.

27. Shengyuan L, Songpo Y, Wen W, Wenjing T, Haitao Z,et al. (2009) Hepatitis $C$ Virus and Lichen Planus; A Reciprocal Association Determined by a Metaanalysis. Arch Dermatol 145:1040-1047.

28. van der Meij EH, van der Waal I (2000) Hepatitis C virus infection and ora lichen planus: a report from The Netherlands. J Oral Pathol Med 29: 255-258.

29. Ingafou M, Porter SR, Scully C, Teo CG (1998) No evidence of HCV infection or liver disease in British patients with oral lichen planus. Int J Oral Maxillofac Surg 27:65-66.

30. Eisen D (2002) The clinical features, malignant potential and systemic associations of oral lichen planus: a study of 723 patients. J Am Acad Dermato 46: $207-214$

31. Chouela E, Abeldaño A, Panetta J, Ducard M, Neglia V, et al. (1996) Hepatitis $\mathrm{C}$ virus antibody (anti-HCV): prevalence in psoriasis. Int J Dermatol 35: $797-$ 799

32. Yamamoto T, Katayama I, Nishioka K (1995) Psoriasis and hepatitis C virus Acta Derm Venereol 75: 482 - 483

33. Taglione E, Vatteroni ML, Martini P, Galluzzo E, Lombardini F, et al, (1999) Hepatitis $C$ virus infection: prevalence in psoriasis and psoriatic arthritis. Rheumatol 26: 370-372.

34. Kartal ED, Colak H, Ozgunes I, Usluer G (2005) Exacerbation of psoriasis due to peginterferon alpha-2b plus ribavirin treatment of chronic active hepatitis $\mathrm{C}$. Chemotherapy 5:167-169.

35. Taylor C, Burns DA, Wiselka MJ (2000) Extensive psoriasis induced by interferon alfa treatment for chronic hepatitis C. Postgrad Med J 76: 365- 367.

36. Quesada JR, Gutterman JU (1986) Psoriasis and alpha-interferon. Lancet. 1: $1466-1468$

37. Agnello V, Abel Glel (1997) Localization of hepatitis C virus in cutaneous vasculitic lesions in patients with type II cryoglobulinemia. Arthritis Rheum 40 : 2007-2015.

38. Ignatova TM, Serov VV, Mukhin NA, Kozlovskaia LV, Milovanova Slu, et al. 2005) [HCV infection and mixed cryoglubulinemia]. Klin Med (Mosk) 83: 37-43.

39. Trejo O, Ramos-Casals M, García-Carrasco M, Yagüe J, Jiménez S, et al. (2001) Cryoglobulinemia: study of etiologic factors and clinical and immunologic features in 443 patients from a single center. Medicine (Baltimore) 80: 252-262.

40. Terrier B, Sène D, Dechartres A, Saadoun D, Ortonne N,, et al. (2011) Systemic vasculitis in patients with hepatitis $C$ virus infection with and without detectable mixed cryoglobulinemia. J Rheumatol 38: 104-110.

41. Terrier Benjamin, Semoun Oren, Saadoun David and et al, (2011) Prognostic Factors in Patients with Hepatitis C Virus Infection and Systemic Vasculitis, Arthritis Rheum 63: 1748-1757.

42. Batisse D, Karmochkine M, Jacquot C, Kazatchkine MD, Weiss L. (2004) Sustained exacerbation of cryoglobulinaemia-related vasculitis following treatment of hepatitis C with peginterferon alfa. Eur J Gastroenterol Hepatol.16: 701-703.

43. Kanazawa K, Yaoita H, Tsuda F, Okamoto H (1996) Hepatitis C virus infection in patients with urticaria, J Am Acad Dermatol 195-198.

44. Schwaber MJ, Zlotogorski A (1997) Dermatologic manifestations of hepatitis C infection. Int J Dermatol. 36: 251-254.

45. Raslan HM, Ezzat WM, Abd El Hamid MF, Emam H, Amre KS (2009) Skin manifestations of chronic hepatitis $C$ virus infection in Cairo, Egypt. East Mediterr Health J 15: 692-700.

46. Cunha VS, Meotti C, Oliveira JH, Sprinz E, Alvares-da-Silva MR (2012) Different patterns of dermatological presentations in patients co-infected with 
Citation: Elshimi E, Darwish HA, Abdelaal EM, Sherify ME, Morad W, et al. (2013) Switch On/Off of Hepatitis C and Major Chronic Skin Diseases in Egyptian Patients: Study of Prevalence, the Impact of, Gender, Viral Load and the Severity of Liver Disease. J Liver 2: 121. doi:10.4172/21670889.1000121

human immunodeficiency virus and hepatitis $\mathrm{C}$ virus (HCV), and those infected with HCV alone. Clin Exp Dermatol 37: 122-127.

47. Siddique N, Pereira BN, Hasan Arshad S (2004) Hepatitis C and urticaria: cause and effect? Allergy 59: 668

48. Cribier BJ, Santinelli F, Schmitt C, Stoll-Keller F, Grosshans E (1999)Chronic urticaria is not significantly associated with hepatitis $C$ or hepatitis $G$ infection: a case-control study. Arch Dermatol 135: 1335-1339.

49. Zauli D, Deleonardi G, Grassi A, Bortolotti R, Lari F, et al. (2001) Chronic urticaria. Ach Dermatol 137: 504- 505

50. Nunley JR (2000) Cutaneous manifestations of HIV and HCV. Dermatol Nurs 12:163- 169 .

51. Tsuboi H, Yonemoto K, Katsuoka K (2006) Vitiligo with infammatory raised borders with hepatitis C virus infection. J Dermatol 33: 577- 578.
52. Kang HY, Wang JB, Zhao ZL, Wang Y, Liu YH ( 2012) A case of anti-HCV treatment in cirrhosis patient with vitiligo. Zhonghua Gan Zang Bing $\mathrm{Za} Z \mathrm{~h}$ 20: 236

53. Tomasiewicz K, Modrzewska R, Semczuk G (2006) Vitiligo associated with pegylated interferon and ribavirin treatment of patients with chronic hepatitis $\mathrm{C}$ a case report. Adv Ther 23: 139- 142

54. Hamadah I, Binamer Y, Sanai FM, Abdo AA, Alajlan A( 2010) Interferoninduced vitiligo in hepatitis $C$ patients: a case seriest J Dermatol. 49: 829- 833

55. Akbayir N, Gökdemir G, Mansur T, Sökmen M, Gündüz S, et al. (2004) Is there any relationship between hepatitis $\mathrm{C}$ virus and vitiligo Clin Gastroenterol 38 : 815-817. 